\title{
Research on How 24 Weeks of Taijiquan Exercises Affect the Elderly People's Peripheral Blood T Lymphocyte Subgroups and NK Cells
}

\author{
Yanqun Wang \\ Sports School \\ Linyi University \\ Linyi City of Shandong Province, China \\ E-mail: wangyanqun@lyu.edu.cn
}

\begin{abstract}
Aims: The research discusses how Taijiquan exercises affect human peripheral Blood $T$ lymphocyte subgroups and NK cells. Methods: Firstly, select 100 elderly citizens, excluding those who have a long exercise history and those who suffer serious organic diseases. Among these 100 subjects, 30 are males with the average age of $61.6 \pm 3.8$ years old and 70 females with the average age of $58.5 \pm 4.1$ years old. Secondly, divide them into two groups, one of which is the experimental group and the other of blank group. People of the experimental group are expected to do Taijiquan exercise 4 times a week for 24 weeks in all . Results: The $\mathrm{CD8}^{+}$of the male subjects in the experimental group decreases sharply with very significant distinction $(\mathrm{P}<0.01)$, while the $\mathrm{CD4}^{+} / \mathrm{CD8}^{+}$ratio increases with significant distinction $(P<0.05)$; for female ones, the activity of $\mathrm{NK}$ cells and the number of $\mathrm{CD}^{+}$ augment with significant distinction $(P<0.05)$, while the $\mathrm{CD8}^{+}$decreases, leading to the increase of $\mathrm{CD4}^{+} / \mathrm{CD8}^{+}$ ratio with very significant distinction $(P<0.01)$. Conclusions: 24 weeks of " Health Qigong•Five-Animal Exercises" will contribute to strengthening natural immunity through improving the NK cell activity.
\end{abstract}

Keywords-Taijiquan; T lymphocyte subgroups; NK cells; immunity

A Chinese traditional sports event, Taijiquan is a kind of aperiodic aerobic exercise characterized by soft movements and flexible gestures. With the speed-up of people' life tempo and the coming of aging society, awareness has been raised among a remarkable number of individuals, especially the elderly, of the significance of Taijiquan exercises, for it functions well in building body, prolonging life and cultivating tastes as well as mind. This article is to probe into how 24 weeks of Taijiquan exercises affect elderly people's peripheral Blood T lymphocyte subgroups and NK cells and figure out how Taijiquan exercises function in helping build body and prolong life so as to provide scientific support for the popularization of Taijiquan.

\section{RESEARCH PARTICIPANTS AND METHODS}

\section{A. Research Participants}

Firstly, select 100 elderly citizens who have no long exercise history and who do not suffer serious organic diseases from a community, including 30 male subjects with the average age of $61.6 \pm 3.8$ years old and 70 female ones with the average age of $58.5 \pm 4.1$ years old. Secondly, divide all the subjects into two groups, either of which includes 15 males and 35 females. Set one as the experimental group in which the subjects are expected to do Taijiquan exercises while the other one as the blank group in which people are supposed to do no fitness exercises.

\section{B. Methods}

1) Methods and Samples. The subjects of the experimental group are expected to do Taijiquan exercises 3-4 times every morning, and for each time it lasts about 45 minutes. For a total 24 weeks, no less than 4 days are scheduled to do so weekly. Whereas the ones of the blank group are required to do no exercises at all. Test both group members for the blood biochemical indexes of before and after the experiment.

2) Test Metric. Immune Indexes: Natural Killer Cell(NK); $\mathrm{CD}_{4}^{+} ; \mathrm{CD}_{8}^{+} ; \mathrm{CD}_{4}^{+} / \mathrm{CD}_{8}^{+}$ratio the total number of $\mathrm{T}$ lymphocytes $\left(\mathrm{CD}_{3}^{+}\right)$

3) Test Methods. Draw elbow venous blood from the subjects of both groups, and provide anticoagulant treatment by adding heparin and then keep them in cold storage. Carry them to the Immunology Lab of People's Hospital of Linyi City for testing. Finally, test and analyze $\mathrm{T}$ lymphocytes and its subgroups with double fluorescent labeling method.

4) Test Instrument. Full-automatic Biochemical Analyzer ( Model: Hitachi 7170A, Japan)

Thermostat Water Bath (Model: DK600, Shenxian Thermostatic Equipment Factory in Shanghai)

5) Statistical Approach. Process data with the statistic software SPSS14.0 and then analyze the results with the paired $\mathrm{T}$ test method. The results can be marked with the format of "mean \pm standard deviation", for example of "58.5 \pm 4.1 ". $\mathrm{P}<0.05$ means it comes up to the significant level, while $\mathrm{P}<0.01$ indicates it comes up to the very significant level.

\section{RESULTS}

The $\mathrm{CD}^{+}$of male subjects in the experimental group decreases markedly and the distinction is very significant $(\mathrm{P}<0.01)$ while the rest indexes do not change sharply. The female ones' NK cell activity and the $\mathrm{CD}_{4}{ }^{+}$improve significantly $(\mathrm{P}<0.05)$, while the $\mathrm{CD}_{8}{ }^{+}$decreases, with the $\mathrm{CD} 4^{+} / \mathrm{CD}^{+}$ratio increasing very significantly $(\mathrm{P}<0.01)$.

See table 1. 
TABLE 1: IMMUNE INDEX CHANGES AFTER 24 WEEKS OF EXERCISES

\begin{tabular}{|c|c|c|c|c|c|c|}
\hline \multirow{2}{*}{$\begin{array}{l}\text { Index } \\
\text { es }\end{array}$} & \multicolumn{3}{|c|}{ Male } & \multicolumn{3}{|c|}{ Female } \\
\hline & $\mathrm{N}$ & $\begin{array}{c}\text { pre-experim } \\
\text { ent }\end{array}$ & $\begin{array}{c}24 \text { weeks } \\
\text { after }\end{array}$ & $\mathrm{N}$ & $\begin{array}{l}\text { pre-experim } \\
\text { ent }\end{array}$ & $\begin{array}{c}24 \text { weeks } \\
\text { after }\end{array}$ \\
\hline $\begin{array}{c}\text { NK(\% } \\
\text { ) }\end{array}$ & $\begin{array}{l}1 \\
3\end{array}$ & $22.02 \pm 10.55$ & $\begin{array}{c}24.49 \pm 12.5 \\
5\end{array}$ & $\begin{array}{l}3 \\
4\end{array}$ & $23.31 \pm 12.37$ & $\begin{array}{c}27.87 \pm 14.1 \\
5^{*}\end{array}$ \\
\hline $\begin{array}{c}\mathrm{CD3}^{+} \\
(\%)\end{array}$ & $\begin{array}{l}1 \\
3\end{array}$ & $53.15 \pm 12.22$ & $\begin{array}{c}49.38 \pm 12.1 \\
8\end{array}$ & $\begin{array}{l}3 \\
4\end{array}$ & $48.78 \pm 14.81$ & $\begin{array}{c}47.22 \pm 13.0 \\
5\end{array}$ \\
\hline $\begin{array}{c}\mathrm{CD}^{+} \\
(\%)\end{array}$ & $\begin{array}{l}1 \\
3\end{array}$ & $42.60 \pm 9.91$ & $\begin{array}{c}44.60 \pm 13.3 \\
4\end{array}$ & $\begin{array}{l}3 \\
4\end{array}$ & $39.01 \pm 7.81$ & $\begin{array}{c}43.20 \pm 9.07 \\
*\end{array}$ \\
\hline $\begin{array}{c}\mathrm{CD}^{+} \\
(\%)\end{array}$ & $\begin{array}{l}1 \\
3\end{array}$ & $28.98 \pm 7.06$ & $\begin{array}{c}20.62 \pm 6.14 \\
* *\end{array}$ & $\begin{array}{l}3 \\
4\end{array}$ & $32.01 \pm 6.79$ & $\begin{array}{c}23.76 \pm 6.67 \\
* *\end{array}$ \\
\hline $\begin{array}{l}\mathrm{CD}^{+} / \\
\mathrm{CD}^{+}\end{array}$ & $\begin{array}{l}1 \\
3\end{array}$ & $1.68 \pm 1.01$ & $2.52 \pm 1.79 *$ & $\begin{array}{l}3 \\
4\end{array}$ & $1.34 \pm 0.62$ & $\begin{array}{c}2.06 \pm 1.04 * \\
*\end{array}$ \\
\hline
\end{tabular}

\section{ANALYSIS}

After 24 weeks of Taijiquan exercises, the NK cell activity of both male and female subjects improves, which is of great statistical significance. As one of the most critical components of innate immune system, NK cell functions broadly in the host's defense system and plays a specially critical role in tumor immunity. This experiment indicts that aerobic exercise of moderate intensity for a long time, for example Taijiquan exercises, contributes to strengthening natural immunity through improving the NK cell activity.

After 24 weeks of Taijiquan exercises, the $\mathrm{CD}_{4}{ }^{+} / \mathrm{CD}_{8}{ }^{+}$ratio of both male and female subjects of the experimental group improves with the decreasing of $\mathrm{CD}_{8}{ }^{+}$. The female subjects' $\mathrm{CD}_{3}{ }^{+}$increases. All these results are of great statistical significance. T lymphocyte is the most important functional cell which bears the greatest number, whose functional activity changes can not only affect the activity of other immune cells but also reflects the functional state of the specific immune system. People always assess the organism's cellular immunity on the basis of the functional activity changes of T lymphocyte. $\mathrm{CD}_{4}{ }^{+}$and $\mathrm{CD}_{8}{ }^{+}$are two $\mathrm{T}$ lymphocyte subgroups with different functions. $\mathrm{CD}_{4}^{+}$works chiefly for assisting and guiding, while $\mathrm{CD}_{8}{ }^{+}$for killing and inhabiting. The ratio of $\mathrm{CD}_{4}{ }^{+}$cell to $\mathrm{CD}_{8}{ }^{+}$cell reflects the immune balance, and the ratio disorder will bring out the malfunction of immunity. Therefore, only when it is in a proper scope, can the body give appropriate immune responses so that they can clear away the foreign antigens but not damage the body itself. In all actuality, people' s immunity is on the decline with aging. And Kishmoto reports that over the years, the total number of $\mathrm{T}$ lymphocyte is decreasing.

According to the results, we see moderate Taijiquan exercises for a long time helps increase the $\mathrm{CD}_{4}{ }^{+} / \mathrm{CD}_{8}{ }^{+}$ ratio and keep $\mathrm{CD}_{4}^{+}$on a proper level; what's more, it augments the total number of T lymphocyte. All in all, Taijiquan exercises play a positive part in adjusting body immunity.

It may attribute to its characteristic of regulating mental activities, and physiology has proved that people' mind can control visceral activities through central nervous system's governing vegetative nervous system. Regulation of mental activities for a long term can help brain to regulate nerves and glands, further to enhance the secretory function of these glands. A host of documents manifest that all these factors will affect the distribution of $\mathrm{T}$ lymphocyte subgroups. One vital psychological effect of Qigong is to enhance mental stability, relieve strain and improve emotional delight. When doing Taijiquan exercises, he should get rid of the emotional changes which goes against health and devote himself to exercises in order to resist a variety of unpleasant stimulation from outside world. Exercise of such kind will indeed help the exercisers raise spiritual delight, relief nervousness, reduce metal pressure and maintain mental health. More importantly, it eases the tensity of brain systems and functions well in preventing psychentonia and melancholia.

\section{CONCLUSIONS}

24 weeks of “ Health Qigong•Five-Animal Exercises” can strengthen people's natural immunity through boosting the activity of NK cells.

\section{REFERENCES}

[1] Peijie Chen. Changes of body immunity after a hard workout and possible relationship with hypophysis-adrenal cortex system[J]. Sports Science.1995, 15(51): 53-64

[2] Crist C M, Etal. Physical exercise increase natura cellular-mediated tumor cytotoxicity in elderly women[J]. Geronotol.1989(35):66.

[3] Nieman D.C. Exercise, upper respiratory tract infection, and the immune system[J]. Med Sci sports Exerc,1994(2):128-139.

[4] Lineng Yang. Psychophysiology[M]. Jiangxi: Jiangxi Technology and Science Press, 1998: 179

[5] AI Dongsheng. How Chinese Magnolia Boxing affects the middle and aged women' peripheral blood T lymphocyte[D]. Shanghai: Shanghai Institute Of Physical Education, 2001:

[6] Hang Zhang. Research on how Health Qigong Exercises affect the peripheral blood T lymphocyte of the middle-aged and elderly people[D]. Shanghai: Shanghai Institute Of Physical Education, 1993:

[7] Sun Li. Development of studies of athletics and immunity in some foreign countries[J]. Chinese Journal of Sports Medicine, 1990, 9(2): 112-115

Author Introductions: Wang Yanqun( 1974- ), Male, born in Linyi City, Shandong Province, China, Associate Professor, Sports School of Linyi University. Research Orientation: Theories and Method of National Traditional Sports. 